\title{
Distance Learning: The Effectiveness Studies In College Students
}

\author{
Rahmat Solihin $^{1}$,M. Tamsil Muin ${ }^{1}$, Muhammad Iqbal ${ }^{1}$ \\ ${ }^{1}$ STAI Asy-Syukriyyah Tangerang \\ *Corresponding email: solihin.elrahmat@gmail.com \\ Naskah diterima: 04 Maret 2021 | Disetujui: 06 April 2021 | Diterbitkan: 07 Mei 2021
}

\begin{abstract}
During the pandemic, distance learning is implemented at schools and universities in Indonesia. However, distance learning had many problems when implemented, such as lack of motivation and limited communication. With some of these problems, distance learning is exciting to research how effective it is in learning. The type of research using a quantitative approach to measure the effectiveness of distance learning, while the subject in this study is PGMI student at STAI AsySyukriyyah Tangerang, samples were taken in this study 29 respondents consisting of all PGMI students. Based on the findings in the study, especially in the research subject, showed that the implementation of distance learning in STAI Asy-Syukriyyah Tangerang, categorized as effective with an adequate level of $63.79 \%$.
\end{abstract}

Keywords: Effectiveness, Distance Learning, College Students

\begin{abstract}
Abstrak
Di masa pandemi, pembelajaran jarak jauh diterapkan di sekolah dan universitas di Indonesia. Namun, pembelajaran jarak jauh memiliki banyak masalah ketika diterapkan, seperti kurangnya motivasi dan komunikasi yang terbatas. Dengan beberapa masalah tersebut, pembelajaran jarak jauh menarik untuk diteliti seberapa efektif pembelajaran tersebut. Jenis penelitian ini menggunakan pendekatan kuantitatif untuk mengukur efektivitas pembelajaran jarakjauh, sedangkan subjek dalam penelitian ini adalah mahasiswa PGMI di STAI Asy-Syukriyyah Tangerang. Sampel yang diambil dalam penelitian ini 29 responden yang terdiri dari seluruh mahasiswa PGMI. Berdasarkan hasil temuan dalam penelitian khususnya pada subjek penelitian menunjukkan bahwa pelaksanaan pembelajaran jarak jauh di STAI Asy-Syukriyyah Tangerang, dikategorikan efektif dengan tingkat cukup sebesar $63,79 \%$.
\end{abstract}

Kata Kunci: Efektivitas, Pembelajaran Jarak Jauh, Mahasiswa 


\section{Introduction}

The pandemic that hit the world forced education to make an innovation. Since the Covid-19 pandemic, the Indonesian government has enacted several policies such as lockdown, physical distancing, the application of health protocols, quarantine, and administrative sanctions to reduce the pandemic spread (Telaumbanua, 2020). These policies certainly have an impact on learning activities, including in universities.

Distance learning is not a new education method in Indonesia. Before the pandemic, we already know the e-learning system that students and lecturers can utilize for lectures. However, there are still very few universities that implement this e-learning comprehensively for their lecture system. However, since the government's policy regarding this pandemic was enacted, schools and campuses have been forced to be ready and enforce distance learning by utilizing all media that can be used to support learning.

Distance Learning is a method of learning using a medium that allows interaction between teachers and learners even if they are not in the same place (Prawiyogi \& Purwanugraha, 2020). Distance learning between teachers and learners does not come face-to-face in person; in other words, it is possible that a very long distance can even separate teachers and learners of different places through distance learning. In distance learning, it is also possible to use blended learning methods where internet-based learning collaborates with non-internet based in order to produce the optimal learning outcomes (Purnama, 2020).

In this case, Sekolah Tinggi Agama Islam (STAI) Asy-Syukriyyah, as one of the accredited universities in the center of Tangerang City, strives to provide the best teaching amid the spread of the Covid-19 pandemic while paying attention to applicable government policies. Various distance learning media are held at STAI Asy-Syukriyyah Tangerang, including Zoom Meeting, Google Meet, Google Classroom, WhatsApp, and other applications that can be used as learning media. The interaction between lecturers and students is very decisive for the success of learning. By using suitable media and methods, good interaction must be maintained so that learning can run effectively (Sari \& Amrozi, 2020).

Previous research has shown that distance learning is less effective in learning (Darsono et al., 2020). Students are not familiar with distance learning, which raises an indication of student stress (Harahap et al., 2020). In addition, several other problems make distance learning less effective during the pandemic, such as lack of motivation (Utama, 2020), limited communication (Hanifah \& Putri, 2020), internet connection problems, an adaptation of learning styles, mastery of technology, reduced integration of exemplary in learning (Solihin, 2020, 2021), as well as a lack of emotional bond between teachers and learners (Prawiyogi \& Purwanugraha, 2020).

With some of these cases, distance learning is fascinating to research how effective it is in learning by now. Because STAI Asy-Syukriyyah is a campus that uses distance learning for about three semesters, especially in Tangerang, a metropolis city, distance learning needs to be researched for its effectiveness. So, the purpose of this research is to find out how effective the implementation of distance learning in college students at STAI Asy-Syukriyyah Tangerang. 


\section{Research Method}

The type of research uses a quantitative approach, and the type of research used is descriptive research. Descriptive research in this study was conducted to determine the value of independent variables, either one variable or more (independent), without making comparisons or connecting between variables with each other.

The research variables in this study are the effectiveness of distance learning. The form of variables is a single variable that means not looking for influence or relationship of other variables but intends to describe the effectiveness of distance learning in students. The sampling techniques in this study used saturated sampling techniques in which all members of the population were used as samples. It was done because the population is relatively small. The number of samples taken in this study amounted to 29 respondents consisting of all students of PGMI, one of the study programs at STAI Asy-Syukriyyah Tangerang.

This research was conducted at the end of the odd semester of the 2020-2021 academic year. The research subjects have carried out this distance learning for two semesters, starting from the even semester of the 2019-2020 school year to continue until the odd semester of 2020-2021. Researchers used an effectiveness test with a Likert scale in the form of multiple-choice (Arikunto, 2003). Furthermore, the data is processed by making percentage with the following analysis formula:

$$
\mathrm{P}=\frac{\left.\sum \text { (acquisition score }\right)}{\sum(\text { Items } x \text { Respondents } x \text { Maximum Skor })} \times 100 \%
$$

The results of the calculation will be interpreted using the effectiveness criteria contained in table 1 below.

Table 1. Effectiveness Criteria

\begin{tabular}{cc}
\hline Percentage & Validity Level \\
\hline $80-100$ & Highly effective \\
\hline $60-79$ & Effective \\
\hline $40-59$ & Less effective \\
\hline $0-39$ & Ineffective \\
\hline
\end{tabular}

This study only looks for the level of effectiveness of distance learning in the specified subject. The researcher only collects data about this without intervening with the results obtained. Conclusions will be drawn based on the results of the calculation of the effectiveness and interpretation of the categories that have been determined in table 1.

\section{Findings}

Researchers have collected data through the dissemination of questionnaires to predetermined samples using Google Form. The questions on the questionnaire amounted to 9 items. Seven questions using the Likert scale and weighted values of $1,2,3$, and 4, then two questions with open 
question form. Two validators have validated this questionnaire before being distributed to respondents. The two validators are Dr. Zubairi Muzakki, M.Pd.I, as an education expert, and Moh. Maulidin A. M.Pd.I. as a distance learning practitioner. Data from the study results on the questionnaire that has been distributed to respondents using a Likert scale questionnaire can be seen in Table 2 below.

Table 2. Questionnaire Findings Data

\begin{tabular}{|c|c|c|c|c|c|c|c|c|}
\hline \multirow[t]{2}{*}{ Respondents } & \multicolumn{7}{|c|}{ Poll Item Number } & \multirow[t]{2}{*}{ Total Score } \\
\hline & 1 & 2 & 3 & 4 & 5 & 6 & 7 & \\
\hline Resp 1 & 3 & 2 & 3 & 3 & 2 & 2 & 1 & 16 \\
\hline Resp 2 & 4 & 3 & 2 & 3 & 3 & 2 & 3 & 20 \\
\hline Resp 3 & 2 & 2 & 3 & 4 & 4 & 4 & 2 & 21 \\
\hline Resp 4 & 3 & 2 & 2 & 2 & 2 & 3 & 1 & 15 \\
\hline Resp 5 & 2 & 2 & 3 & 2 & 2 & 3 & 1 & 15 \\
\hline Resp 6 & 1 & 3 & 3 & 3 & 3 & 3 & 3 & 19 \\
\hline Resp 7 & 3 & 3 & 3 & 2 & 2 & 2 & 2 & 17 \\
\hline Resp 8 & 4 & 3 & 3 & 2 & 2 & 3 & 3 & 20 \\
\hline Resp 9 & 3 & 3 & 2 & 3 & 2 & 4 & 2 & 19 \\
\hline Resp 10 & 2 & 2 & 2 & 2 & 2 & 3 & 2 & 15 \\
\hline Resp 11 & 3 & 2 & 3 & 2 & 2 & 2 & 1 & 15 \\
\hline Resp 12 & 2 & 3 & 3 & 3 & 3 & 3 & 1 & 18 \\
\hline Resp 13 & 3 & 3 & 3 & 3 & 3 & 3 & 2 & 20 \\
\hline Resp 14 & 2 & 2 & 2 & 2 & 2 & 2 & 2 & 14 \\
\hline Resp 15 & 2 & 2 & 2 & 2 & 2 & 2 & 2 & 14 \\
\hline Resp 16 & 3 & 2 & 2 & 2 & 2 & 2 & 1 & 14 \\
\hline Resp 17 & 2 & 2 & 2 & 3 & 3 & 2 & 3 & 17 \\
\hline Resp 18 & 3 & 3 & 3 & 2 & 2 & 3 & 2 & 18 \\
\hline Resp 19 & 3 & 3 & 3 & 4 & 3 & 3 & 2 & 21 \\
\hline Resp 20 & 2 & 3 & 3 & 3 & 2 & 3 & 1 & 17 \\
\hline Resp 21 & 4 & 4 & 3 & 3 & 3 & 3 & 2 & 22 \\
\hline Resp 22 & 3 & 2 & 2 & 2 & 2 & 3 & 1 & 15 \\
\hline Resp 23 & 2 & 2 & 3 & 3 & 2 & 2 & 2 & 16 \\
\hline Resp 24 & 4 & 3 & 3 & 3 & 3 & 3 & 2 & 21 \\
\hline
\end{tabular}




\begin{tabular}{lllllllll}
\hline $\operatorname{Resp} 25$ & 3 & 4 & 4 & 3 & 3 & 3 & 3 & $\mathbf{2 3}$ \\
\hline $\operatorname{Resp} 26$ & 3 & 3 & 3 & 4 & 4 & 4 & 2 & $\mathbf{2 3}$ \\
\hline $\operatorname{Resp} 27$ & 2 & 2 & 2 & 3 & 2 & 3 & 2 & $\mathbf{1 6}$ \\
\hline $\operatorname{Resp} 28$ & 3 & 2 & 2 & 2 & 2 & 3 & 1 & $\mathbf{1 5}$ \\
\hline $\operatorname{Resp} 29$ & 3 & 3 & 3 & 3 & 3 & 4 & 3 & $\mathbf{2 2}$ \\
\hline
\end{tabular}

Data from the study results on the questionnaire that has been shared with respondents using open questions can be seen in Table 3 below.

Table 3. Open Question Findings Data

\begin{tabular}{|c|c|}
\hline Number & $\begin{array}{l}\text { Apakah ada kendala saat mengikuti kegiatan pembelajaran jarak jauh ini? Jika } \\
\text { ada, sebutkan! }\end{array}$ \\
\hline 1 & Sinyalnya putus puteus terkadang..jadi kurang jelas menjelaskannya \\
\hline 2 & Ada ,kuota \\
\hline 3 & Jaringan \\
\hline 4 & Terkendala jaringan atau sinyal, Serta Ucapan dosen saat mengajar kurang jelas \\
\hline 5 & Terkadang terkendala jaringan \\
\hline 6 & $\begin{array}{l}\text { Ada, pada saat pjj pembahasan materi oleh dosen di apk untuk meeting sering } \\
\text { terkendala jaringan yang tidak bagus sehingga suaranya pun putus-putus. Lalu } \\
\text { kurangnya interaksi antara dosen dan mahasiswa. }\end{array}$ \\
\hline 7 & Miskomunikasi, sehingga dosen jadi agak lebih sensitif dengan mahasiswanya (-) \\
\hline 8 & Kendala kuota perlu banyak, kendala jaringan \\
\hline 9 & Kuota internet habis, sinyal kurang mendukung \\
\hline 10 & $\begin{array}{l}\text { Kendalanya bagi saya adalah "Signal" karna di kampung saya tidak ada signal sama } \\
\text { sekali, jadi hanya menggunakan wifi, dan jika mati lampu atau wifi nya ada } \\
\text { gangguan (eror)maka saya tidak bisa ikut pembelajaran. }\end{array}$ \\
\hline 11 & $\begin{array}{l}\text { apabila menggunakan aplikasi google meet atau zoom untuk penjelasan materi nya } \\
\text { kurang dikarenakan internet yg tidak stabil }\end{array}$ \\
\hline 12 & Kendala di internet/kuota dan sinyal \\
\hline 13 & Kendalanya akan kurang fham dengan materi yang disampaikan \\
\hline 14 & Jaringan dan kouta \\
\hline 15 & Sinyal, kurang jelas saat menjelaskan karena gangguan sinyal \\
\hline 16 & Jaringan dan kuota \\
\hline
\end{tabular}


17 Kurang menguasai materi dan mata sering sakit karna selalu melihat gadget bahkan sering pusing karna layar gadget

18 Jaringan internet

19 Sinyal kadang buruk, sehingga sulit mengerti saat pembelajaran

20 Jaringan

21 Signal dan kuota

22 Kendala signal saja

23 Ada ,kendala sinyal,

$24 \quad$ Sinyal internet

\section{Number Berikan saran anda untuk teknis pembelajaran jarak jauh!}

1 Saran saya pembelajaran jarak jauh itu sama seperti kemarin..lewat wa atau zoom atau google meet

$2 \quad$ Jangan terlalu banyak tugas

3 Sarannya ialah semoga interaksi antara dosen dan mahasiswa lebih aktif, semoga pembelajaran lebih asik dan seru meski menggunakan jarak jauh

4 Dosen harus membuat peraturan sendiri terkait Pembelajaran jarak jauh

5 Sebaiknya untuk teknis pembelajaran jarak jauh dosen harus fleksibel. Saat cuaca buruk lebih baik tidak menggunakan apk meeting room, dosen bisa menggunakan apk massager seperti whatsapp sebagai alternative.

6 Harus lebih fleksibel saat pembelajaran atau memberi tugas, tidak membani.

$7 \quad$ Untuk para dosen yg terhormat, kami para mahasiswa meminta tolong agar jika diberikan tugas, bekali lah kami dengan materi nya terlebih dahulu, demi kenyamanan dosen dan mahasiswa dalam mempelajari ilmu tersebut,. Terimakasih

$8 \quad$ Menurut saya untuk teknis pembelajaran jarak jauh saat ini sudah membantu peserta didik untuk memahami pelajaran tersebut, meskipun mungkin ada sedikit gangguan dari jaringan yg menyebabkan peserta didik tidak mampu menguasai materi yg diberikan oleh dosen.

Jadi, semoga wabah covid 19 ini cepat berakhir dan peserta didik secepatnya belajar secara tatap muka.

9 apabila menyampaikan materi di upload di youtube apabila berdiskusi bisa di google meet, zoom, googleclass dan WA

10 Di bagiin kuota sesuai dengan kebutuhan mahasiswa dalam pembelajaran 
11 Sebaiknya Dosen bisa memberikan penjelasan baik lisan maupun tulisan. Karna terkadang jika dengan lisan saja tidak semua mahasiswa memiliki tipe belajar audio, teradang ada yang audio dan visual. Agar materi dengan mudah di pahami

12 Saran dan masukkan untuk guru sekolah dan pemerintah selama pembelajaran jarak jauh selama covid 19 :

Gunakanlah media pembelajaran yang lain untuk membantu menjelaskan materi ajar kepada peserta didik

Guru perlu mencermati jumlah, tingkat kesulitan, dan tanggal penyerahan tugas

Diperlukan menjalin komunikasi yang baik dengan orangtua atau wali murid

Penjelasan :

Pembelajaran di masa pandemi (DARING) tidak boleh menekankan pada suatu penuntasan dari pencapaian akademik dan kelulusan siswa. Dengan kondisi yang seperti itu, semua guru sebaiknya tidak memberikan materi yang terlalu banyak agar orang tua dan siswa tidak terlalu stres karena yang terpenting itu learning how to learn, bukan hanya how to learn .

Tugas yang banyak tanpa penyampaian materi yang baik, akan membuat siswa mudah cepat lelah dan tidak bisa fokus belajar. Yang pada akhirnya, para siswa akan merasa sulit belajar karena suasana belajar yang tak nyaman dan kondusif . Banyak laporan bahwa siswa merasa stres ketika pembelajaran daring, hal tersebut sama dengan penyiksaan terhadap anak atas nama pendidika $n$.

13 Dosen ttp menjelaskan menggunakan media seperti papan tulis atau lain2 agar tidak hanya melalui metode ceramah saja, saat PJJ semua kamera di hidupkan.

14 Koneksi internet dosen yang harus memadai

15 Sarannya ialah semoga interaksi antara dosen dan mahasiswa lebih aktif, semoga pembelajaran lebih asik dan seru meski menggunakan jarak jauh

16 Dosen bisa melakukan metode pembelajaran yang lebih menarik, untuk menambah semangat mahasiswa, afwan

17 Menggunakan media pembelajaran yang lain untuk membantu menjelaskan materi ajar kepada peserta didik

18 Penyampaian materi harus lebih ditingkatkan agar mahasiswa lebih mudah memahami

19 Saran saya adalah menyampaikan materi walau sedikit tapi fokus dari pada banyak pa jang lebar tetapi tidak fokus.

20 Sarannya ialah semoga interaksi antara dosen dan mahasiswa lebih aktif, semoga pembelajaran lebih asik dan seru meski menggunakan jarak jauh 


\section{Discussion}

\section{Validity Test Result}

Before analyzing the data of the findings into effectiveness tests, a validity test is carried out first on each question item so that the findings can present more valid results. This validity test is done using SPSS 26. with the following test results below.

Table 4. Validity Test Value Output with SPSS. 26

\section{Correlations}

\begin{tabular}{l|l|l|l|l|l|l|l} 
Item1 & Item2 & Item3 & Item4 & Item5 & Item6 & Item7 & Skor_Total
\end{tabular}

\begin{tabular}{|c|c|c|c|c|c|c|c|c|c|}
\hline \multirow[t]{3}{*}{ Item1 } & Pearson Correlation & 1 & $.431^{*}$ & .107 & -.035 & .065 & .045 & .077 & $.405^{*}$ \\
\hline & Sig. (2-tailed) & & .020 & .581 & .858 & .739 & .817 & .691 & .029 \\
\hline & $\mathrm{N}$ & 29 & 29 & 29 & 29 & 29 & 29 & 29 & 29 \\
\hline \multirow[t]{3}{*}{ Item2 } & Pearson Correlation & $.431^{*}$ & 1 & $.603^{* *}$ & $.368^{*}$ & $.430^{*}$ & .340 & $.452^{*}$ & $.804^{* * *}$ \\
\hline & Sig. (2-tailed) & .020 & & .001 & .049 & .020 & .071 & .014 & .000 \\
\hline & $\mathrm{N}$ & 29 & 29 & 29 & 29 & 29 & 29 & 29 & 29 \\
\hline \multirow[t]{3}{*}{ Item3 } & Pearson Correlation & .107 & $.603^{* *}$ & 1 & $.381^{*}$ & $.390^{*}$ & .223 & .175 & $.610^{* *}$ \\
\hline & Sig. (2-tailed) & .581 & .001 & & .041 & .036 & .244 & .363 & .000 \\
\hline & $\mathrm{N}$ & 29 & 29 & 29 & 29 & 29 & 29 & 29 & 29 \\
\hline \multirow[t]{3}{*}{ Item4 } & Pearson Correlation & -.035 & $.368^{*}$ & $.381^{*}$ & 1 & $.798^{* *}$ & $.448^{*}$ & .304 & $.717^{* *}$ \\
\hline & Sig. (2-tailed) & .858 & .049 & .041 & & .000 & .015 & .109 & .000 \\
\hline & $\mathrm{N}$ & 29 & 29 & 29 & 29 & 29 & 29 & 29 & 29 \\
\hline \multirow[t]{3}{*}{ Item5 } & Pearson Correlation & .065 & $.430^{*}$ & $.390^{*}$ & $.798^{* *}$ & 1 & $.463^{*}$ & $.424^{*}$ & $.789^{* *}$ \\
\hline & Sig. (2-tailed) & .739 & .020 & .036 & .000 & & .011 & .022 & .000 \\
\hline & $\mathrm{N}$ & 29 & 29 & 29 & 29 & 29 & 29 & 29 & 29 \\
\hline \multirow[t]{3}{*}{ Item6 } & Pearson Correlation & .045 & .340 & .223 & $.448^{*}$ & $.463^{*}$ & 1 & .111 & $.581^{* *}$ \\
\hline & Sig. (2-tailed) & .817 & .071 & .244 & .015 & .011 & & .566 & .001 \\
\hline & $\mathrm{N}$ & 29 & 29 & 29 & 29 & 29 & 29 & 29 & 29 \\
\hline \multirow[t]{3}{*}{ Item7 } & Pearson Correlation & .077 & $.452^{*}$ & .175 & .304 & $.424^{*}$ & .111 & 1 & $.583^{* *}$ \\
\hline & Sig. (2-tailed) & .691 & .014 & .363 & .109 & .022 & .566 & & .001 \\
\hline & $\mathrm{N}$ & 29 & 29 & 29 & 29 & 29 & 29 & 29 & 29 \\
\hline \multirow{3}{*}{$\begin{array}{l}\text { Skor_T } \\
\text { otal }\end{array}$} & Pearson Correlation & $.405^{*}$ & $.804^{* *}$ & $.610^{* *}$ & $.717^{* *}$ & $.789^{* *}$ & $.581^{* *}$ & $.583^{* *}$ & 1 \\
\hline & Sig. (2-tailed) & .029 & .000 & .000 & .000 & .000 & .001 & .001 & \\
\hline & $\mathrm{N}$ & 29 & 29 & 29 & 29 & 29 & 29 & 29 & 29 \\
\hline
\end{tabular}

*. Correlation is significant at the 0.05 level (2-tailed).

**. Correlation is significant at the 0.01 level (2-tailed). 
Based on the output "Correlations" in table 4, Sig's value can be known. (2-tailed) for each question item in the questionnaire represented by Item1 through Item7. Then this value is compared to the r-table with a significance level of $5 \%$ and $\mathrm{N}$ amounting to 29 , which is 0.367 . The result is that all question items in the questionnaire are valid because r-count > r-table. So that it can be concluded that each item of question in the questionnaire with this instrument can be used because it is valid.

\section{Reliability Test Result}

Reliability test on questionnaire instrument also using the same application, SPSS. 26 with the output result of the following values.

Table 5. Output Reliability Test Value with SPSS. 26

Reliability Statistics

\begin{tabular}{r|r}
$\begin{array}{c}\text { Cronbach's } \\
\text { Alpha }\end{array}$ & N of Items \\
\hline .755 & 8 \\
\hline
\end{tabular}

\section{Item-Total Statistics}

\begin{tabular}{|c|c|c|c|c|}
\hline \multicolumn{5}{|c|}{ tistics } \\
\hline & $\begin{array}{l}\text { Scale Mean if } \\
\text { Item Deleted }\end{array}$ & $\begin{array}{l}\text { Scale Variance } \\
\text { if Item Deleted }\end{array}$ & $\begin{array}{c}\text { Corrected } \\
\text { Item-Total } \\
\text { Correlation }\end{array}$ & $\begin{array}{l}\text { Cronbach's } \\
\text { Alpha if Item } \\
\text { Deleted }\end{array}$ \\
\hline Item 1 & 33.00 & 31.214 & .289 & .754 \\
\hline Item 2 & 33.14 & 28.695 & .761 & .711 \\
\hline Item3 & 33.07 & 30.567 & .546 & .735 \\
\hline Item 4 & 33.03 & 29.106 & .655 & .719 \\
\hline Item5 & 33.24 & 28.761 & .742 & .712 \\
\hline Item6 & 32.90 & 30.167 & .499 & .734 \\
\hline Item7 & 33.83 & 29.791 & .492 & .733 \\
\hline Skor_Total & 17.86 & 8.552 & 1.000 & .749 \\
\hline
\end{tabular}

From the calculation results in table 5, it is known that the reliability level of this questionnaire is 0.755. Similarly, the "Cronbach's Alpha" score for each question item is $>0.367$, so it can be categorized as a high-reliability questionnaire. So that it can be concluded that each item of question in the questionnaire with this instrument can be used because it is worth the reliability. 


\section{Questionnaire Data Analysis}

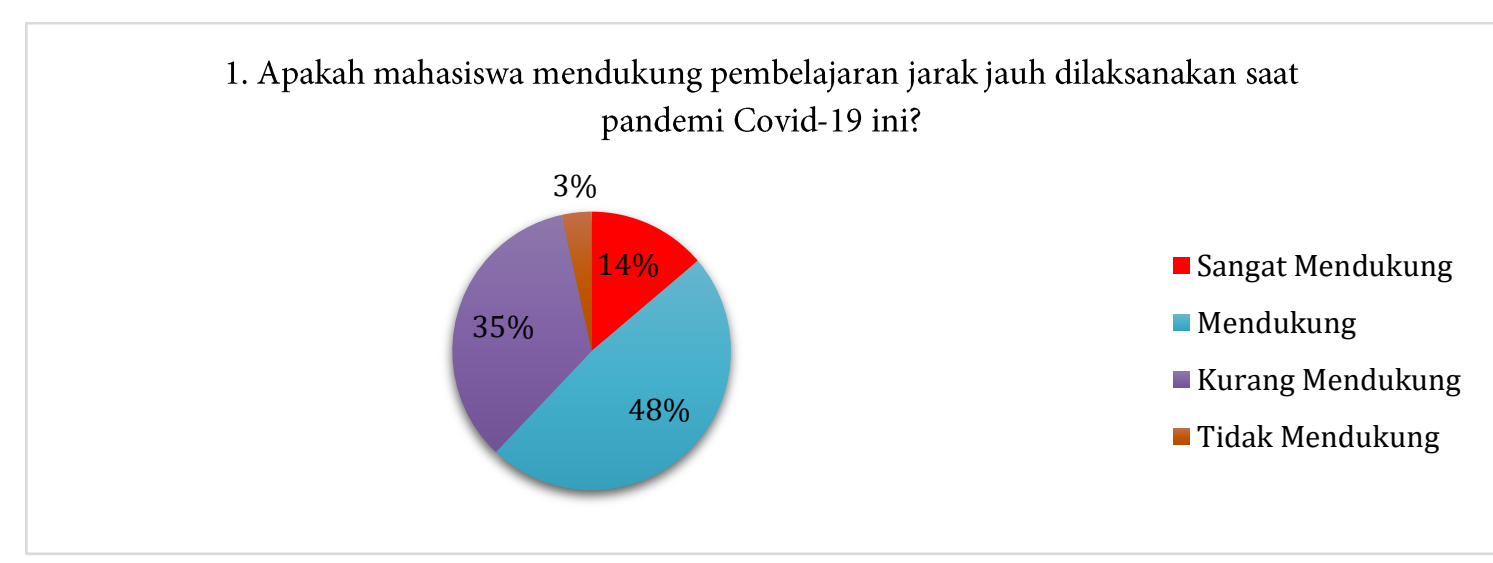

\section{Figure 1. Graph of Question Questionnaire Data 1}

The answers were dominated by respondents who supported distance learning implemented during the Covid-19 pandemic, with a score of $48 \%$ of the total respondents. It means that students understand the distance learning policy implemented by the campus as a form of implementation of government policy.

2. Apakah pembelajaran jarak jauh ini mudah untuk dilaksanakan?

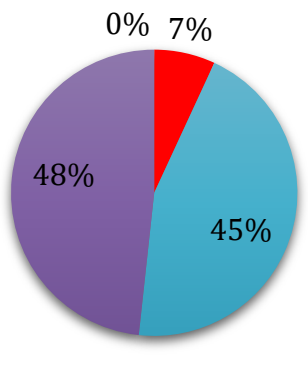

- Sangat Mudah

Mudah

Sulit

- Sangat Sulit

\section{Figure 2. Graph of Question Questionnaire Data 2}

From question 2, it can be known that the majority of students find it challenging to learn this distance. There are $48 \%$ who think that distance learning is challenging to implement.

3. Apakah rata-rata dosen menguasai dengan baik sistem pembelajaran jarak jauh

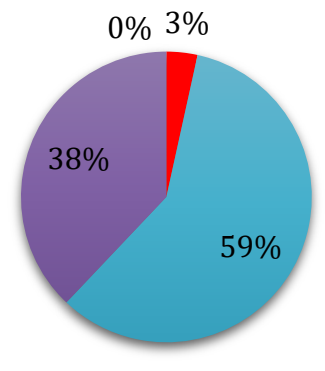

- Sangat menguasai

$\square$ Menguasai

- Kurang menguasai

Tidak menguasai

Figure 3. Graph of Question Questionnaire Data 3 
Figure 3 shows that more than half of $59 \%$ of the total respondents think the average lecturer teaches mastering the distance learning system well. This means that the lecturer mastered the distance learning system well.

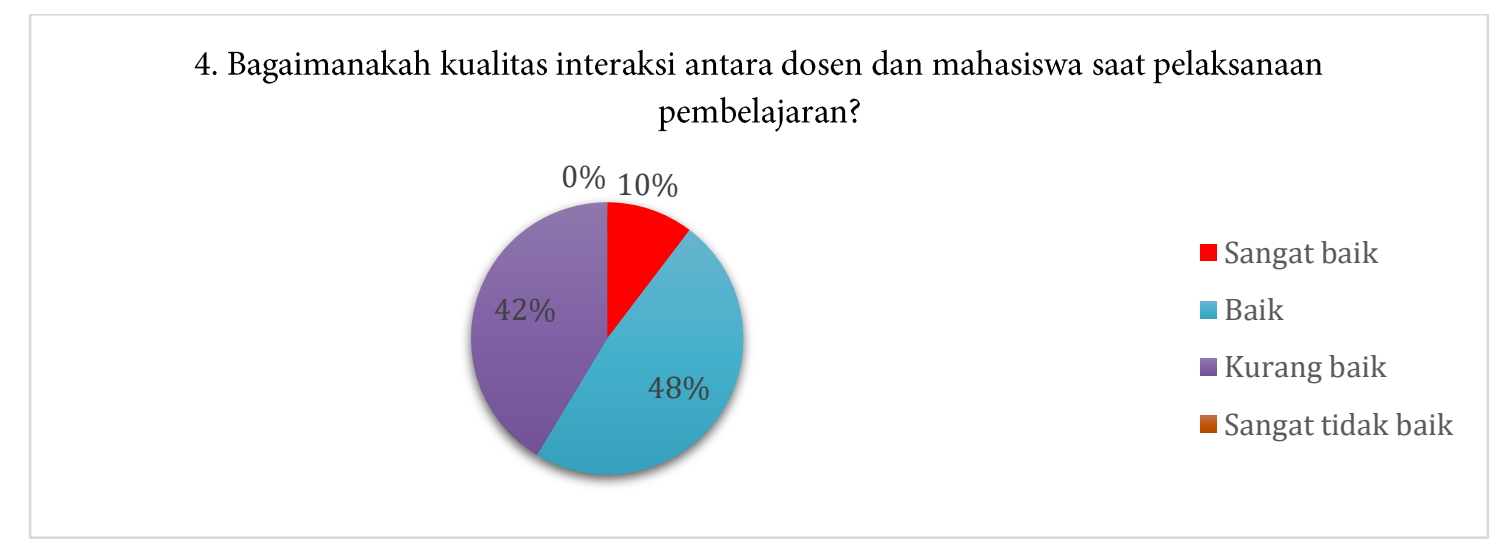

Figure 4. Graph of Questionnaire Question 4 Data

The data in figure 4 shows that the quality of interaction between lecturers and students during the implementation of distance learning is at a reasonable level, with the value of $48 \%$ of the total respondents stating the quality of interaction is good.

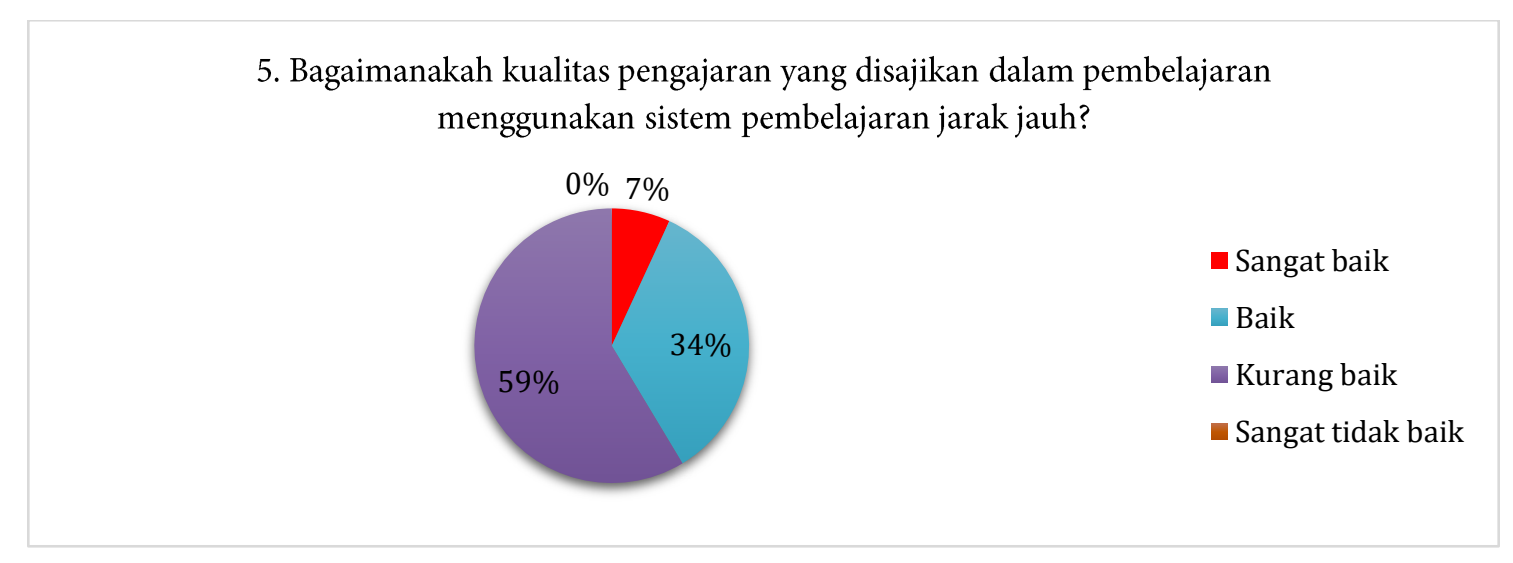

Figure 5. Graph of Question Questionnaire Data 5

Figure 5 shows that the quality of teaching presented in learning using distance learning systems is not so good. It appears that more than half of $59 \%$ of the total respondents stated that the quality of teaching was not good. 
6. Apakah bahan ajar atau referensi lebih mudah ditemukan saat pelaksaanaan pembelajaran jarak jauh?

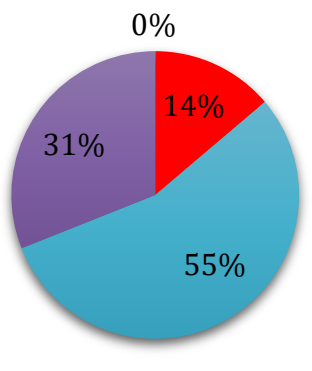

- Sangat mudah

Mudah

- Sulit

- Sangat sulit

\section{Figure 6. Graph of Question Questionnaire Data 6}

Figure 6 shows that teaching materials or references are easier to find when performing distance learning. It was proven that more than half of $55 \%$ of the total respondents stated that teaching materials or references were easy to find.

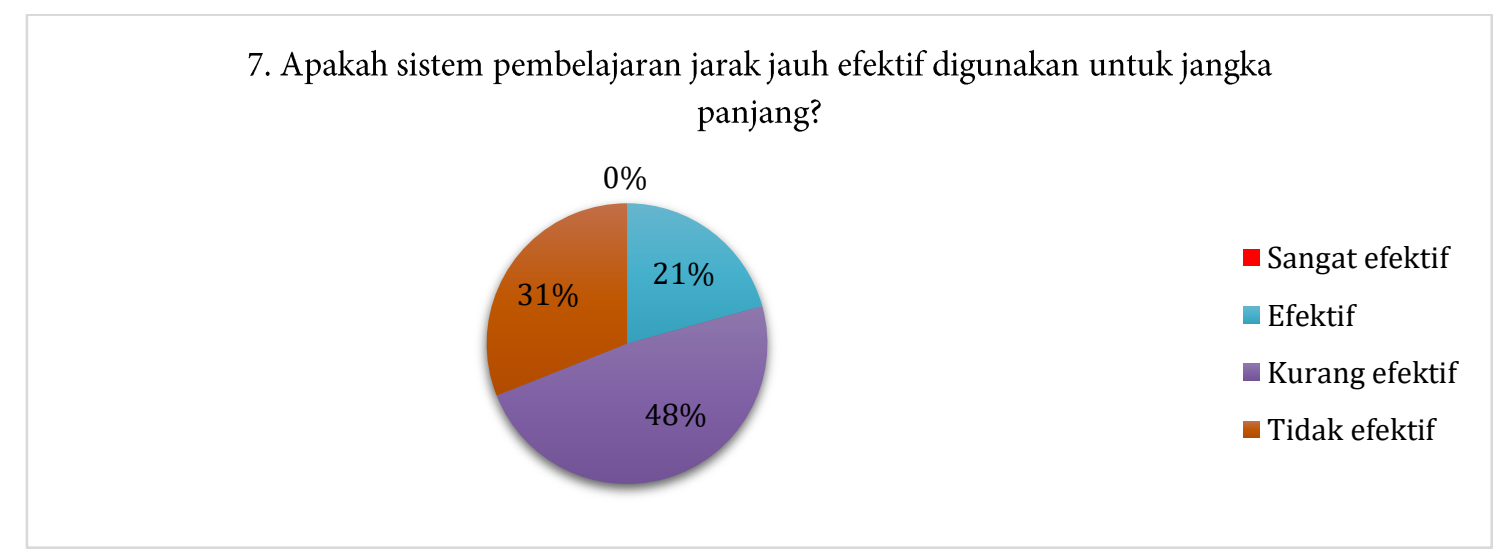

Figure 7. Graph of Question Questionnaire Data 7

The data in figure 7 shows that most respondents think distance learning systems are less effective for long-term use. Some $48 \%$ said it was less effective, and even $31 \%$ stated that distance learning systems were not effectively used for the long term.

\section{Effectiveness Test Result}

Based on the data of the findings that have been obtained, the following calculation is carried out with the method that has been determined as follows.

$\mathrm{P}=\frac{\left.\sum \text { (acquisition score }\right)}{\sum(\text { Items } x \text { Respondents } \times \text { Maximum Skor })} \times 100 \%$

$\mathrm{P}=\frac{\sum(518)}{\sum(812)} \times 100 \%$

$\mathrm{P}=63,79 \%$ 
Data analysis of the above findings is then matched with table 1 . So it can be seen that the effectiveness of distance learning in college students is $63.79 \%$ and is in the practical category. Thus, it can be concluded that distance learning in the subjects runs effectively.

Previous studies showed that distance learning was less effective than face-to-face learning in class. This is due to the unfamiliarity of students with this method. Then, after time has passed since this distance learning treatment, students begin to get used to it and find the right learning style (figure 2) so that distance learning becomes more effective than before. Students accept that a policy to implement distance learning is the right choice in education (figure 1). Even so, students still expect that learning in class can be carried out again (figure 7).

Some students suggested that the current distance learning quality should be continuously improved. For example, using suitable media such as writing instruments to help explain the material to students (table 3) and the delivery of material and assignments that pay more attention to the condition of students when distance learning is in progress (Table 3). Of course, data on this study should continue to be researched because of the limitations of research and distance learning that are still ongoing today. Several campuses and students make many innovations also understand better their methods when learning this distance.

\section{Conclusion}

Based on the findings in the study, especially in the research subject, college students of PGMI showed that the implementation of distance learning in STAI Asy-Syukriyyah Tangerang, categorized as effective with an adequate level of $63.79 \%$. This shows an increase compared to previous studies that consider that distance learning has many problems and shows less effectiveness. So, it can be concluded that distance learning in college students is compelling. Of course, the results of this research must be studied more thoroughly about what constraints occur during the implementation of distance learning to improve the quality of learning in the future.

\section{Referrence}

Arikunto, S. (2003). Dasar-Dasar Evaluasi Pendidikan. Bumi Aksara.

Darsono, H., Fitri, A. N., Rahardjo, B., Imanuela, M. Z., Akuntansi, J., \& Bandung, P. N. (2020). Efektivitas Pembelajaran Jarak Jauh saat Pandemi Covid-19 ( Kajian di Politeknik Negeri Bandung ). Industrial Research Workshop and National Seminar, 19, 26-27.

Hanifah, W., \& Putri, K. Y. S. (2020). EFEKTIVITAS KOMUNIKASI GOOGLE CLASSROOM SEBAGAI MEDIA PEMBELAJARAN JARAK JAUH PADA MAHASISWA ILMU KOMUNIKAI UNIVERSITAS NEGERI JAKARTA ANGKATAN 2018 THE EFFECTIVENESS OF GOOGLE CLASSROOM COMMUNICATION AS A DISTANCE LEARNING MEDIA IN COMMUNICATION STUDIES. MEDIALOG: Jurnal Ilmu Komunikas, III(II), 24-35.

Harahap, A. C. P., Harahap, D. P., \& Harahap, S. R. (2020). Analisis Tingkat Stres Akademik Pada Mahasiswa Selama Pembelajaran Jarak Jauh Dimasa Covid-19. Biblio Couns : Jurnal Kajian Konseling Dan Pendidikan, 3(1), 10-14. 
Prawiyogi, A. G., \& Purwanugraha, A. (2020). Efektifitas pembelajaran jarak jauh terhadap pembelajaran siswa di sdit cendekia purwakarta. JPD: Jurnal Pendidikan Dasar, 94-101.

Purnama, M. N. A. (2020). Blended Learning Sebagai Sarana Optimalisasi Pembelajaran Daring Di Era New Normal. SCAFFOLDING: Jurnal Pendidikan Islam Dan Multikulturalisme, 2(02), 106-121. https://doi.org/10.37680/scaffolding.v2i02.535

Sari, D. R., \& Amrozi, F. (2020). Analisis Efektivitas Pembelajaran Jarak Jauh ( PJJ ) di Politeknik Penerbangan Surabaya ( Studi Kasus Saat Terjadi Wabah Covid-19 ). Jurnal Penelitian Politeknik Penerbangan Surabaya, 5(2), 1-10.

Solihin, R. (2020). Akidah dan Akhlak dalam Perspektif Pembelajaran PAI di Madrasah Ibtidaiyah. Ibriez: Jurnal Kependidikan Dasar Islam Berbasis Sains, 5(1), 83-96. https://doi.org/https://doi.org/10.21154/ibriez.v5i5.92

Solihin, R. (2021). AKIDAH AKHLAK DALAM PERSPEKTIF PEMBELAJARAN DI MADRASAH IBTIDAIYAH. Penerbit Adab.

Telaumbanua, D. (2020). Urgensi Pembentukan Aturan Terkait Pencegahan Covid-19 di Indonesia. QALAMUNA: Jurnal Pendidikan, Sosial, Dan Agama, 12(01), 59-70. https://doi.org/10.37680/qalamuna.v12i01.290

Utama, M. M. A. (2020). STUDENT MOTIVATION IN THEMATIC LEARNING AT ELEMENTARY SCHOOLS. Southeast Asian Journal of Islamic Education, 03(01), 1-21. 


\section{IDENTITAS PENULIS*}

*) Mohon diisi secara lengkap, agar memudahkan proses komunikasi saat review!

$\begin{array}{lll}\text { Nama } & : \text { Rahmat Solihin } \\ \text { Tempat Tgl Lahir } & : \text { Banjarmasin, 29 Juni } 1992 \\ \text { Alamat Domisili } & : \text { Jl. Utama Kpg Gunung, Poris Plawad, Cipondoh } \\ & & \text { Tangerang, Banten } \\ \text { Afiliasi/Instansi } & : & \text { STAI Asy-Syukriyyah Tangerang } \\ \text { Pendidikan S1 } & : & \text { IAIN Antasari Banjarmasin } \\ \text { Pendidikan S2 } & : & \text { UIN Maulana Malik Ibrahim Malang } \\ \text { Pendidikan S3 } & : & - \\ \text { Bidang Keahlian } & : & \text { Pendidikan Dasar, Pendidikan Islam } \\ \text { Nomor WA } & : & \text { 0813 } 48216770\end{array}$


Distance Learning: The Effectiveness Studies In College Students

Rahmat Solihin, M. Tamsil Muin, Muhammad Iqbal 